go far beyond the title and cover most kinds of work on influenza virus. Melnick's article, too, has a misleading title; it is not at all concerned with poliomyelitis as a disease, but is an admirable account of current knowledge on the virus. Bennett's is probably the best account yet given of his subject; but the subject is narrower than the title suggests, for he considers only plant viruses.

Two articles deal with insects, one as vectors of plant viruses and the other as sufferers from infection. Black's can be paid the compliment of saying that many who live where leaf hopper-transmitted viruses are not yet troublesome would have welcomed more detail. Bergold shows his belief that viruses are organisms by being the only author to give them Latin binomial names, which, incidentally, are already invalid. His apparent lack of interest in the fascinating problems raised by the survival of 'latent' viruses through many generations of insects seems unaccountable.

Markham's essay will be valued by the many pathologists who know little about either the structure or functions of nucleic acids; but it is to be hoped they will not take resistance to nucleases as 'direct evidence' that nucleic acid is held internally in viruses. It may well be, but if we reason the same way from their resistance to proteases, the protein, too, must be held internally. In attempting to cover too much, Sharp has produced a rather scrappy result, which will be useful mainly as a guide to the literature.

At the start of a series, it was perhaps deliberate policy to summarize broad subjects; but this should not continue. This volume amply shows that more satisfactory articles come from the critical examina. tion of limited topics. In future volumes, too, references should be cited uniformly; some authors now refer by numbers whereas others use the better method of names with dates, and some list only journal references whereas others give the titles of papers.

The volume is excellently produced, with detailed author and subject indexes. In the United States the price may seem ressonable; but for the sterling area it is regrettably high.

F. C. BAWDEN

\section{STATISTICAL EXERCISES}

\section{Elementary Statistical Exercises, Part I}

Issued by the Department of Statistics, University College, London. Pp. 91. (1952.) 6s. 6d. net.

\section{Introduction to Statistical Calculations}

By J. Mounsey. Pp. 351. (London : English Universities Press, Ltd., 1952.) 15s. net.

Statistical Tables and Problems

By Prof. Albert E. Waugh. Third Edition. Pp. xiv + 242. (London: McGraw-Hill Publishing Co., Ltd., 1952.) 25s. $6 d$.

COOD exercises in statistics are hard to find. The $\checkmark$ essential statistical point is apt to get lost in arithmetical calculations or in pure mathematical analysis. Artificial examples lose that contact with reality which all statistical teachers try to maintain ; and examples from the real world become contaminated with practical considerations which are off the essential point. Some statistical text-books do not attempt the setting of exercises at all ; and, among those which do so, there are often many trivial examples and a shortage of good solid ones on which the student may test his knowledge, his grasp of fundamentals and his technical expertise.

The volumes under notice are attempts to fill this gap. The exercises from University College, London, are based on an unrivalled experience of class-work accompanying first-year lectures to undergraduate students taking the B.Sc. (Special) degree in statistics of the University of London. They are all numerical and, broadly speaking, cover univariate theory, regression and correlation, chi-squared and significance tests, sampling distributions and quality control. A second volume is promised to cover variance analysis, experimental design, correlation, probit and discriminant analysis, and curve fitting. The book is very legibly reproduced from typescript and its price is extraordinarily low. One suggestion might very well be made: Could not future editions give the answers, or at least some of the main sums of squares and products, to lighten the burden of a teacher who sets an exercise to ten students and is presented with ten different answers?

Mr. J. Mounsey's useful little book contains about six hundred numerical exercises, but is more than a mere collection. His wealth of examples is knit together by introductory text so that the methods of calculation are explained in detail. The book is designed primarily for students in commercial and technical colleges who are preparing for examinations in statistics, and should prove very useful for that purpose. Its scope is about that of the certificate of the Royal Statistical Society-averages, index numbers, estimates of error, dispersion, lines of best fit, moments, elements of probability, binomial, Poisson and normal distributions and significance tests. There are some tables of the usual kind, and answers to the exercises are provided.

Prof. A. E. Waugh's book, now in its third edition, consists of 35 tables, a list of 137 formulæ and a set of about 450 numerical exercises for class work. Many of the tables are of the standard type; but there are one or two unusual (and useful) ones, such as a perpetual Gregorian calendar and a table of the Julian day. No answers are provided, alas, but the exercises contain an abundance of stimulating material.

Teachers and students alike should be grateful for the tedious work which has gone to the making of these collections.

\section{ZOOLOGICAL RECORD FOR I95I}

\section{The Zoological Record}

Vol. 88. Being the Records of Zoological Literature relating chiefly to the Year 1951. Edited by G. Burder Stratton. Pp. vi +592. (London: Zoological Society of London, 1953.) $120 s$.

$T$ HE appearance in November 1953 of the eightyeighth volume of the "Zoological Record" is a notable achievement, for the editor and recorders have at last reduced the delay in publication, caused by the War, to less than two years, thereby much increasing the usefulness of the "Record". Some idea of the task involved may be gathered when it is considered that all zoological publications during the year in question have to be examined and the titles of papers abstracted and afterwards distributed 